\title{
Editorial
}

Journal of Innate
Immunity
J Innate Immun 2019;11:301-302

DOI: $10.1159 / 000500357$
Received: April 15, 2019

Accepted: April 15, 2019

Published online: June 5, 2019

\section{The Extracellular Matrix: Reloaded Revolutions}

Since the first review article on bacterial biofilm formation was published in 1990 [1], this field of research has still been expanding exponentially, as seen by the number of publications, which almost exceeded 2,000 articles in 2018. The reason why this topic is receiving so much attention is easy to explain: biofilm formation contributes to antibiotic resistance and tolerance in pathogenic bacteria [2]. Thus, also the Journal of Innate Immunity has recently devoted increasing attention to this topic [3-8]. Notably, the extracellular matrix plays an important role in the formation of biofilms, since it provides a surface for bacteria to attach to and colonize.

In this issue, Binsker et al. [9] provide an excellent summary of the contribution of human thrombospondin-1 to the pathogenesis of gram-positive bacteria. Thrombospondin-1 is a matricellular protein that is involved in the regulation of extracellular matrix function. As outlined in the review article, in vitro data have shown that Streptococcus pneumoniae and Staphylococcus aureus species interact with thrombospondin-1 in order to adhere to different cells and eventually invade them, but also the interaction with soluble platelet-derived thrombospondin-1 is discussed. Neutrophils are not only important phagocytosing cells, they also play important roles in modulating inflammatory host responses [10]. Moraes et al. [11] report in this issue that the interaction of lowmolecular-weight fucoidan, a polysaccharide extracted from brown algae, with neutrophils can alter their inflammatory responses, making this substance an interesting template for the development of novel anti-inflammatory drugs. Not only eukaryotic cells can release vesicle-like organelles, also bacteria have this ability, as described in an article by Bae et al. [12]. In their study, an unexpected therapeutic use of the bacterial outer membrane vesicles was found, suggesting that these could be applied to provide protection against lethal Influenza $A$ virus infections, as shown in a mouse model. The authors further note that this effect was caused by the mobilization of macrophages, but not neutrophils. Keeping in mind that some influenza infections are associated with high morbidity and mortality [13], the concept presented by Bae et al. may lead to novel strategies in the treatment of severe viral infections. Macrophages also play an important role in the article published by Muraleedharan et al. [14]. As seen for many other cells $[15,16]$, also gene expression in macrophages can be regulated by microRNAs. In their article, Muraleedharan et al. provide evidence that conserved miR-183/96/182 clusters can regulate the production of reactive nitrogen and oxygen species in activated macrophages, which may be an alternative option to combat antibiotic-resistant bacterial infections. Apart from microRNAs, the regulation of macrophages can be altered by many other substances, one of them being bacterial lipopolysaccharide (LPS) [17, 18]. CD14 plays an important role in LPS-induced signaling via toll-like receptors. In their contribution to this issue, Grahnert et al. [19] describe that blockage of CD14 results in an overproduction of proinflammatory cytokines only in $\mathrm{M}-\mathrm{M} \Phi$ but not GM-M $\Phi$ when stimulated with LPS. These results suggest that CD14 may determine the outcome of bio-

\begin{tabular}{ll}
\hline KARGER & $\begin{array}{l}\text { @ } 2019 \text { The Author(s) } \\
\text { Published by S. Karger AG, Basel Openger }\end{array}$ \\
E-Mail karger@karger.com & This article is licensed under the Creative Commons Attribution- \\
www.karger.com/jin & $\begin{array}{l}\text { NonCommercial-NoDerivatives 4.0 International License (CC BY- } \\
\text { NC-ND) (http://www.karger.com/Services/OpenAccessLicense). } \\
\text { Usage and distribution for commercial purposes as well as any dis- } \\
\text { tribution of modified material requires written permission. }\end{array}$
\end{tabular}


logical responses by interacting with different subsets of macrophages. Type 1 diabetes is characterized by destruction of insulin-producing pancreatic $\beta$ cells by cytotoxic T cells. Colli and co-workers [20] show that group $\mathrm{B}$ coxsackievirus infection, a putative causative factor for type 1 diabetes, induces ER stress in $\beta$ cells, promoting a pro-viral response. The findings open new avenues for the treatment of enterovirus-associated diseases. As always, we hope that this collection of articles will increase the interest of the reader in the Journal of Innate Immunity.

Arne Egesten, Lund Heiko Herwald, Lund

\section{References}

1 Ladd TI, Costerton JW. Methods for studying biofilm bacteria. Methods Microbiol. 1990; 22:285-307.

2 Hall CW, Mah TF. Molecular mechanisms of biofilm-based antibiotic resistance and tolerance in pathogenic bacteria. FEMS Microbiol Rev. 2017 May;41(3):276-301.

3 Williams DE, Boon EM. Towards understanding the molecular basis of nitric oxideregulated group behaviors in pathogenic bacteria. J Innate Immun. 2019;11(3):205-15.

4 Turkina MV, Vikström E. Bacteria-host crosstalk: sensing of the quorum in the context of Pseudomonas aeruginosa infections. J Innate Immun. 2019;11(3):263-79.

5 Lesouhaitier O, Clamens T, Rosay T, Desriac F, Louis M, Rodrigues S, et al. Host peptidic hormones affecting bacterial biofilm formation and virulence. J Innate Immun. 2019; 11(3):227-41.

6 Yamada KJ, Kielian T. Biofilm-leukocyte cross-talk: impact on immune polarization and immunometabolism. J Innate Immun. 2019;11(3):280-8.

7 Dostert M, Belanger CR, Hancock REW. Design and assessment of anti-biofilm peptides: steps toward clinical application. J Innate Immun. 2019;11(3):193-204.

8 Riquelme SA, Ahn D, Prince A. Pseudomonas aeruginosa and Klebsiella pneumoniae adaptation to innate immune clearance mechanisms in the lung. J Innate Immun. 2018;10(56):442-54.
9 Binsker U, Kohler TP, Hammerschmidt S. Contribution of human thrombospondin-1 to the pathogenesis of gram-positive bacteria. I Innate Immun. DOI: 10.1159/000496033.

10 Chatfield SM, Thieblemont N, Witko-Sarsat V. Expanding neutrophil horizons: new concepts in inflammation. J Innate Immun. 2018; 10(5-6):422-31.

11 Moraes JA, Frony AC, Barcellos-de-Souza P, Menezes da Cunha M, Brasil Barbosa Calcia $\mathrm{T}$, Benjamim CF, et al. Downregulation of microparticle release and pro-inflammatory properties of activated human polymorphonuclear neutrophils by LMW fucoidan. J Innate Immun. DOI: 10.1159/000494220.

12 Bae EH, Seo SH, Kim CU, Jang MS, Song MS, Lee TY, et al. Bacterial outer membrane vesicles provide broad-spectrum protection against Influenza virus infection via recruitment and activation of macrophages. J Innate Immun. DOI: 10.1159/000494098.

13 Kobzik L. Searching for a lifeline: transcriptome profiling studies of influenza susceptibility and resistance. J Innate Immun. 2017; 9(3):232-42.

14 Muraleedharan CK, McClellan SA, Ekanayaka SA, Francis R, Zmejkoski A, Hazlett LD, et al. The miR-183/96/182 cluster regulates macrophage functions in response to Pseudomonas aeruginosa. J Innate Immun. DOI: $10.1159 / 000495472$.
15 Sadio M, Tourneur E, Bens M, Goujon JM, Vandewalle A, Chassin C. Cyclosporine A induces microRNAs controlling innate immunity during renal bacterial infection. J Innate Immun. 2018;10(1):14-29.

16 Lu Y, Qin Z, Wang J, Zheng X, Lu J, Zhang X, et al. Epstein-Barr virus miR-BART6-3p inhibits the RIG-I pathway. J Innate Immun. 2017;9(6):574-86.

17 Kinoshita M, Miyazaki H, Nakashima $\mathrm{H}, \mathrm{Na}$ kashima M, Nishikawa M, Ishikiriyama T, et al. In vivo lipopolysaccharide tolerance recruits CD11b+ macrophages to the liver with enhanced bactericidal activity and low tumor necrosis factor-releasing capability, resulting in drastic resistance to lethal septicemia. J Innate Immun. 2017;9(5):493-510.

18 Tak T, van Groenendael R, Pickkers P, Koenderman L. Monocyte subsets are differentially lost from the circulation during acute inflammation induced by human experimental endotoxemia. J Innate Immun. 2017;9(5):46474.

19 Grahnert A, Weiss R, Schilling E, Stanslowsky N, Sack U, Hauschildt S. CD14 counterregulates lipopolysacharide-induced tumor necrosis factor- $\alpha$ production in a macrophage subset. J Innate Immun. DOI: 10.1159/ 000495528.

20 Colli ML, Paula FM, Marselli L, Marchetti P, Roivainen M, Eizirik DL, Op de beeck A. Coxsackievirus $B$ tailors the unfolded protein response to favour viral amplification in pancreatic $\beta$ cells. J Innate Immun. DOI: $10.1159 / 000496034$. 